\title{
The Influence of Brand Images on Purchase Motivation of Motorcycle Products
}

\author{
$1^{\text {st }}$ L Rohmawati \\ Program Studi Pendidikan Ekonomi \\ STKIP Pangeran Dharma Kusuma \\ Segeran Juntinyuat Indramayu \\ Indonesia \\ lutfirahmawati40@gmail.com \\ $4^{\text {th }}$ T Kuryanto \\ Program Studi Pendidikan Ekonomi \\ STKIP Pangeran Dharma Kusuma \\ Segeran Juntinyuat Indramayu \\ Indonesia
}

\author{
$2^{\text {nd }} Y$ Susilo \\ Program Studi Pendidikan Ekonomi \\ STKIP Pangeran Dharma Kusuma \\ Segeran Juntinyuat Indramayu \\ Indonesia
}

$5^{\text {th }}$ M Suebudin

Program Studi Pendidikan Ekonomi

STKIP Pangeran Dharma Kusuma

Segeran Juntinyuat Indramayu

Indonesia

\author{
$3^{\text {rd }}$ P S Zevender \\ Program Studi Pendidikan Ekonomi \\ STKIP Pangeran Dharma Kusuma \\ Segeran Juntinyuat Indramayu \\ Indonesia
}

\begin{abstract}
The brand image of an item or product can influence consumer decisions or motivate consumers to buy the product (both because of past experience in using it and proximity to the brand and its various characteristics). In this regard, the authors conducted research on the effect of brand image on the purchase motivation of Yamaha motorcycle products. The objective of research should be to determine the effect of brand image on purchasing motivationof Yamaha motorcycle products. To assist in the research process, the author uses the descriptive correlational method, with data collection techniques used are questionnaires or questionnaires. The statistical test tool used to analyze research data is the $R$ square test. Based on the test results it is known that the brand image has a positive effect on purchasing motivation of Yamaha motorcycle products with a correlation coefficient of 0.985 , the magnitude of the coefficient of determination ( $R$ Square) contained is $\mathbf{9 7 . 1 \%}$ meaning that the brand image variable has a contribution or influence on purchasing motivation and the remaining $2,9 \%$ were influenced by other factors.
\end{abstract}

Keywords-Brand Image, Purchase Motivation, Yamaha Motorcycles.

\section{INTRODUCTION}

With the increase in science and technology, spurring more and more growth of industries that produce goods and services, such as the automotive industry which is growing rapidly, especially motorcycles. This results in consumers becoming increasingly meticulous and critical in choosing goods and services that suit their needs, so this becomes a record and a problem that must be considered by every company because it will cause intense competition between these companies.

In addition to the main business competition issues faced by producers to market their products, market decisions in determining the products used are also a problem for producers. This market decision stems from consumers' motivation for the products used. The decision expected by a company for the products it markets is the focus it will achieve. To achieve customer motivation in buying products is not easy because the company must be able to create a good impression on consumers so that it can be influenced.

So that the resulting product can affect consumer motivation, it must have a surefire marketing strategy. Image and brand management are things that must be considered, so that companies can retain consumers. Brand image is one important element that can encourage consumers to buy a product, because the brand can reflect about a product. The better the brand image attached to the product, the more consumers will be interested in buying the product.

Merk deserve not only favored. Above the decorum, the brand also spread the image / aura that is Keku a tan active life in the public imagination. Marketers say that consumers look for brands that suit their needs and desires and a good impression in the eyes of the public. [1]

To attract the attention of consumers, brand image must be firmly attached to the hearts of consumers. A strong brand image of a product will encourage motivated consumers to make a purchase. Brand imagery can influence consumer confidence and motivate consumers to make purchases (both because of past experience in using it and proximity to a brand and its various characteristics). Brand image provides a description of the brand of a product, if the image is obtained, the brand will live in the minds of consumers and if not the brand is just a dead thing that does not have the aura / power to influence consumers. [2] Even more important is the fact that perceived quality and brand association can increase consumer satisfaction in using products. Products in the form of goods or services that already have high imaging values or brands that are already well-known among the 
community are not difficult to develop, other things that are not yet known.

The phenomenon that occurs the authors find among students. As the soul of the next generation, known as intellectuals. The average student has a high critical level, including in buying and using various products. In general, students will prefer products that are clearly known for quality, well-known and have a good image in the community.

From there the authors are interested in researching the influence of brand image on the purchase motivation of Yamaha motorcycle products. This study aims to determine whether brand image influences the purchase motivation of Yamaha motorcycle products.

Where the brand image can be interpreted as a way for people to perceive (think about) the company or its products. [3] Giving the brand name of a product becomes very important because that is what differentiates it from the products of competitors, in addition to the $p$ emberian brand is also beneficial for consumers and producers. The benefits of brand names for consumers include; make it easier for consumers to research products or services, assist consumers or buyers in obtaining the same quality of goods, if they repurchase and in price. Whereas producers have functions as identity, quality, loyalty and image.

While the motivation to have meaning as $\mathrm{k}$ esediaan to issue a high level of effort toward the goal - the goals to be achieved, which is conditioned by the effort's ability to satisfy an individual requirement . [4] In addition, motivation can be described as a driving force that forces them to act. The driving force is produced by a depressed state, which arises as a result of unmet needs.[5] The behavior or actions shown by a person in an effort to achieve certain goals are very dependent on the motives they have. The factors that influence consumer motivation for purchasing decisions include product, price, service and location. Which of the four factors, the most influential on motivation to decide on a purchase is a product. The higher the brand image of a product, the higher the level of trust someone has to make a purchase.

\section{METHOD}

In this study the method that I use is a descriptive correlational research method. This method is used to find out the presence or absence of correlation variables or make predictions based on correlations between variables. The measurement used in this study uses a Likert scale. The population in this study were the students of SMK Cendikia Utama Kuningan with a sample of all the students of SMK Cendikia Utama totaling 100 students. Meanwhile the data collection techniques used a research instrument in the form of a questionnaire or questionnaire.

\section{DATA ANALYSIS}

Data analysis technique used in this study is to use the analysis of the Instrument Data Test, Regression Analysis

\section{RESULTS AND DISCUSSION \\ A. Results \\ 1. Data Quality Test.}

The data quality test is intended to determine the level of validity and reliability of the two instruments used in the study, namely the Brand Image and Purchase Motivation instruments. This data quality test was carried out on 100 respondents who were SMK Cendikia Utama students. From the results of the calculation of the validity test, showed that from 18 statements submitted to respondents declared valid. In addition to being valid, research instruments must also be reliable. The reliability of Brand Image testing was carried out using the SplitHalf Spearman-Brown formula which was processed with the help of the SPSS 12.0 For Windows Program. The results can be seen at the bottom of this .

TABEL I. RELIABILITY RESULTS OF BRAND IMAGE VARIABLES (X) AND PURCHASE MOTIVATION (Y) .

\begin{tabular}{|l|l|l|l|}
\hline Variable & $\mathrm{R}$ value calculated & $\mathrm{R}_{\text {table value }}$ & Information \\
\hline Var X & 0.966 & .195 & Reliable \\
\hline Var Y & 0,900 & .195 & Reliable \\
\hline
\end{tabular}

In the Reliability Statistics section, it can be seen that the Split-Half Spearman-Brown variable (X) brand image is 0.966 with a total of 18 question items. The value of $r$ table at the $95 \%$ confidence level or $5 \%$ significance $(\mathrm{p}=$ 0.05 ) in the statistical books that is 0.195 . Because the value of Spearman Brown $=0.966$ turned out to be greater than $\mathrm{r}$ table $=0.195$, the questionnaire tested was proven to be reliable.

As for the variable $(\mathrm{Y})$ purchase motivation, it can be seen that the Split-Half Spearman-Brown value is 0.900 with a total of 18 question items or items. The value of $r$ table at the $95 \%$ confidence level or $5 \%$ significance $(\mathrm{p}=$ 0.05 ) in the statistical books that is 0.195 . Therefore Splithalf-Half value $=0,900$ turned out to be more substantial than $\mathrm{r}$ tabel $=0.195$, then the questionnaires were tested try proved reliable.

\section{Normality Test.}

Normality test is done to find out whether the sample is normally distributed or not, before the author first converts ordinal data (Likert scale) into interval type data. The normality test results of the two variables were analyzed using the SPSS 12.0 For Windows Program. Based on the results of normality calculations the ChiSquare value of 26,700 with a probability of 0.809 (ASymp. Sig. (2-tailed)). brand image variables in 100 samples are normal, or meet the normality test requirements. S hile purchase motivation variable values obtained Chi-Square is 48,800 with a probability of 0.16 (asymp. Sig. (2-tailed)). Then the purchase motivation variable data on 100 samples is normal, or meets the normality test requirements.

3. Hypothesis Test.

After being tested for normality and the results of both variables were normally distributed, then the next step is the hypothesis of research by using SPSS 12.0 for Wndows in Model Summary (b) at the bottom of this : 


\begin{tabular}{|c|c|c|c|c|c|c|c|c|c|}
\hline \multirow[t]{2}{*}{ Model } & \multirow[t]{2}{*}{$\mathrm{R}$} & \multirow[t]{2}{*}{ R Square } & \multirow[t]{2}{*}{$\begin{array}{l}\begin{array}{l}\text { Adjusted } \\
\text { Square }\end{array} \\
\end{array}$} & \multirow[t]{2}{*}{$\begin{array}{l}\text { Std. Error of } \\
\text { the Estimate }\end{array}$} & \multicolumn{5}{|c|}{ Change Statistics } \\
\hline & & & & & $\begin{array}{l}\mathrm{R} \text { Square } \\
\text { Change }\end{array}$ & F Change & df1 & $\mathrm{df} 2$ & $\begin{array}{l}\text { Sig. } \quad \mathrm{F} \\
\text { Change }\end{array}$ \\
\hline 1 & $.985(\mathrm{a})$ & .971 & .970 & 1.366 & .971 & 3255.921 & 1 & 98 & .000 \\
\hline
\end{tabular}

a Predictors: (Constant), Citra Merek

b Dependent Variable: Motivation_Purchase

Based on the analysis with the SPSS Program, 12 For Windows obtained correlation coefficient or rxy $=0.985$, significant at the 0.05 level of trust, the relationship between brand image and purchase motivation is classified in the high category.From the analysis conducted based on the results of SPSS calculations for windows the correlation coefficient can be 0.985 then the magnitude of the coefficient of determination ( $\mathrm{R}$ Square) is $97.1 \%$ meaning that the brand image variable has a contribution or influence on purchasing motivation and the remaining $2.9 \%$ is influenced by factors other.

The equation model used in analyzing this regression is: $=\mathrm{a}+\mathrm{bx}$ To determine the value of $\mathrm{a}$ and $\mathrm{b}$ calculated through the SPSS 12.0 For Windows Program. The results of the regression equation : $=\mathrm{a}+\mathrm{bx}==9,124+0,806 \mathrm{X}$

a. A constant of 9,124 states that if no brand image is given, the purchase motivation has a value of 9,124.

b. The regression coefficient of 0.806 states that each increase of one unit of brand image levels will increase the value of purchase motivation by 0.806 .

Furthermore, it can also be tested for the significant level of influence of brand image on the purchase motivation of the $t$-value. Where the $t$ value in the brand image is 57,061. At the free degree $(\mathrm{df})=\mathrm{N}-2=100-2=$ 98 , the value of $\mathrm{t}$ table at the $95 \%$ confidence level (significance of $5 \%$ ) is 1.984 . Because $t$ arithmetic $>\mathrm{T}$ table, then $\mathrm{H} 0$ is rejected, meaning that the purchase motivation variable has a significant effect on brand image.

B. Discussion

1. Overview of Brand Image of Yamaha Motorcycle

Products (Variable X).

Of the 100 respondents who perceive the brand image of Yamaha motorcycle products according to SMK Cendikia Utama students, there are high categories of 31 respondents or $31 \%$, medium categories of 67 respondents or $67 \%$, while low categories are 2 respondents or $2 \%$. Cumulatively, according to the perception of SMK Cendikia Utama students the brand image of Yamaha motorcycle products is $65 \%$. This includes the medium category with an interval of $34 \%-67 \%$.

2. Motivation Overview of Purchasing Yamaha

Motorcycle Products (Variable Y).

Of the 100 respondents who stated the description of purchase motivation was a high category of 10 respondents or $10 \%$, a medium category of 89 respondents or $89 \%$, while a low category of 1 respondent or $1 \%$. In cumulative, picture motivation purchase products bike Yamaha on vocational students Main Wise by $63 \%$. It is included in the category of the criterion of being at a distance interval $34 \%-67 \%$. From these percentages, it shows that the description of the motivation to purchase SMK Cendikia Utama Kuningan students is moderate .

3. The Effect of Brand Image on Motivation to Purchase

Yamaha Motorbikes.

From the analysis conducted based on the results of SPSS calculations for windows the correlation coefficient can be 0.985 then the magnitude of the coefficient of determination ( $\mathrm{R}$ Square) is $97.1 \%$ meaning that the brand image variable has a contribution or influence on purchasing motivation and the remaining $2.9 \%$ is influenced by factors other. Furthermore, it can also be tested for the significant level of influence of brand image on the purchase motivation of the $t$-value. Where the $t$ value in the brand image is 57.061. At the free degree (df) $=\mathrm{N}-2=100-2=98$, the value of $\mathrm{t}$ table at the $95 \%$ confidence level (significance of 5\%) is 1.984 . Because $\mathrm{t}$ arithmetic $>\mathrm{T}$ table, then $\mathrm{H} 0$ is rejected, meaning that the purchase motivation variable has a significant effect on brand image. Of course this can be a reference for the institution or company that manufactures Yamaha motorcycles in knowing the level of imaging of a product so that it can improve it for the creation of high purchase motivation. This is in line with the opinion of Engel et al who was quoted [1] as saying that there are several factors that influence consumer behavior including: cultural factors, social factors, personal factors, psychological factors. Where in the main psychological factors, namely the purchase motivation to meet a need. Respondents assume that the brand image owned by Yamaha motorcycle products is in accordance with the wishes and expectations of consumers. So that this research is in line with the theory according to Kotler and Keller cited in [6] which states that brand image is how a brand influences the perceptions, views of the public or consumers regarding the company or its products. In addition, the results of this study are also consistent with the results of research conducted by [7] which shows that simultaneous brand image influences purchasing decisions. Furthermore the results of previous studies that support this research conducted by [8] have an argument which states that "brand image will directly influence the high interest in buying a product". In other words, brand image has nonmaterial benefits that consumers consider in achieving satisfaction levels. Yamaha motorcycle products are wellknown motorcycle brands, especially among Cendikia Utama Vocational High School students. Most respondents find it easy to recognize the Yamaha logo. 
Brand name awareness plays an important role in the process of motivating consumers to buy the product, if the customer has heard the brand name and believes in the product, the customer will feel more comfortable when making a decision to buy it.

\section{CONCLUSIONS}

Based on the results of analysis and statistical testing of the data obtained about the effect of brand image on purchase motivation, the authors can draw conclusions based on the results of calculations using the significance test, which can be interpreted that brand image has a positive influence on purchase motivation. This can be seen from the calculation of the correlation coefficient of 0.985 , the magnitude of the coefficient of determination ( $\mathrm{R}$ Square) contained in the table is $97.1 \%$ meaning that the brand image variable has a contribution or influence on purchasing motivation and the remaining $2.9 \%$ is influenced by factors other.

\section{REFERENCES}

[1] B. Simarora, Panduan Riset Pelaku Konsumen. Jakarta: PT.Gramedia, 2002.

[2] F. Tjiptono, Strategi Pemasaran. Yogyakarta: Andi, 2011.

[3] Kotler, Manajemen Pemasaran. Jakarta: Indeks-Prentice Hall, 2014.

[4] N. J. Setiadi, Perilaku konsumen: konsep dan implikasi untuk strategi dan penelitian pemasaran. Jakarta: Kencana, 2003.

[5] Schiffman dan Kanuk, Perilaku konsumen. Jakarta: Indeks, 2008.

[6] E. Setiawati and A. Anggarani Winadi Prasetyoning Tyas, "Pengaruh harga dan citra merek terhadap keputusan Pembelian televisi samsung di perumahan villa grand tomang Tangerang," Pros. Semin. Nas. MULTI DISIPLIN ILMU CALL Pap. UNISBANK SENDIU, no. Kajian Multi Disiplin Ilmu untuk Mewujudkan Poros Maritim dalam Pembangunan Ekonomi Berbasis Kesejahteraan Rakyat, Agustus 2015.

[7] D. Irana Dewi Lubis and R. Hidayat, "Pengaruh citra merek dan harga terhadap keputusan pembelian pada Sekolah tinggi ilmu manajemen sukma medan," J. Ilman, vol. 5, Feb. 2017, [Online]. Available: http://journals.synthesispublication.org/index.php/ilman.

[8] D. Azis Muthalib, "The effect of price, brand and after-sales service to the purchasing decision motorcycles yamaha matic at PT.Hasjrat abadi brand Kendari," Int. J. Sci. Eng. Res., vol. 9, no. 4, Apr. 2018 